\title{
Income Tax Regime- Old Vs New
}

\author{
Tushar D. Bagul \\ Department of Commerce, K. K. W Arts, Science, Commerce and Computer Science College Chandori, \\ 422201, Nashik, MS (India)
}

\begin{abstract}
The Government of India has announced new tax slab in Union Budget 2020-21. This new tax slab is also called as Optional tax regime because Government has not abolished old tax regime. The tax payer has option to choose the tax regime i.e. either Old or New which is better for them. The new tax regime has lower tax slab as compared to old tax structure. The taxpayer has given an option to either choose new tax structure with lower tax slab or the old tax one with tax benefit but higher tax slabs. The old tax regime enable taxpayer to avail existing tax exemption such as Leave Travelling Allowance, House Rent Allowance \& deductions available under Income Tax Act, 1961. While those who are opting new tax regime will not have to avail advantages of existing exemptions \& deductions that are available under old tax regime. The old tax regime has higher tax rate and three tax slab, whereas new tax regime has lower tax rate \& six tax slabs. There is similarity in tax rate in case of individual below 60 years of age in both tax regime as it is exempted up to 2.5 lakh. In addition to this as per Section 87A (Introduced in Finance Act, 2003) Individual who is resident of India for Income Tax purpose, is entitled to claim tax rebate up to Rs. 12,500 against tax liability if his/her Income does not exceed Rs.5,00,000 for old as well as new tax regime.
\end{abstract}

Keywords: Income Tax, Tax Slab, Exemptions, Deductions, Old Vs New Tax Regime.

\section{INTRODUCTION}

The objective of this research article is to understand Tax structure of India and the difference between Old Tax regime \& New Tax regime \& its implication. Income Tax is a kind of tax that government levies on individual \& businesses. Income taxes are the source of revenue for government, they are used to fund public services, pay government obligations etc. As per Income Tax Act, 1961 every Individual or Artificial Person (Corporate Body) has to pay income tax whose income goes beyond threshold limit set by act. ${ }^{11}$ Income Tax is a percentage that individual person or businesses paid to the Government to run nation smoothly, Infrastructural development etc. Tax Compliance by citizens implies compliance with all statutory obligations specified in the tax law, including registration as a taxpayer, maintaining required records, filing timely, accurate tax returns and paying taxes correctly and on time. ${ }^{[2]}$ All taxes are levied based on finance act passed by government. Income Tax plays an important role as a source of revenue and effective measure to remove disparity. After Independence, each $\&$ every aspect of Indian tax system was studied thoroughly and all possible attempts were made to make system equitable. ${ }^{[3]}$ The Income Tax system has a three tier federal structure. The tax structure consists of the central government, state government and local municipal bodies. ${ }^{[4]}$ There are two type of taxation system in India i.e. Direct Taxes \& Indirect Taxes. Income Tax falls under direct tax system. The direct tax collection in India has been increasing continuously since 30 years. ${ }^{[5]}$ The Tax collection involves some money cost for government and compliance cost for taxpayer. Government should minimise administrative cost but it doesn't mean to decrease administrative staff but administration should make effective \& efficient. [6] The new tax regime is not 
allowed taxpayer to avail the various exemptions or deductions available in old tax regime. However taxpayer can take the advantage of decrease tax rate upon his/her income. One of the most important sovereign functions of any government is the collection of tax for development, security and governance. [9] Developing countries rely much on taxation system for development of Economy. ${ }^{[10]}$

\section{METHODOLOGY}

In this article researcher analysed what's the new tax regime about and difference between old tax regime \& new tax regime. The study has taken the help of various websites, journals, social sites, reference book to analyse what's the new tax slab about. The study also took help of various articles, newspaper, and government report to point out opinion about tax structure. The study is mostly depends on secondary source of data. The main aim behind the study is to get to know the taxpayer which tax regime is beneficial for them; so from that point of view researcher give analytical perspective to see which tax regime beneficial for taxpayers.

\section{RESULT \& DISCUSSION}

In the budget of 2020 Finance Minister Nirmala Sitharaman has announced new tax regime. The new tax regime come with more tax slab and lower tax rates; however the taxpayer can't avail the exemptions \& deductions which are available in old tax regime. The taxpayer also gets confusion because they have provided choice between new tax regime \& old tax regime. Due to this decision tax structure become complex as which tax regime good for taxpayer. Every taxpayer is wondering whether which tax regime should they opt and we are going to analyse the same in this paper.

First we will start with comparison between the old tax regime \& new tax regime. The new tax regime is different than old in two aspects:-

\begin{tabular}{|l|l|}
\hline Aspect: 1 \\
$\begin{array}{l}\text { In new tax regime the number of tax slab is increases and tax rates are } \\
\text { decreases comparatively. }\end{array}$ \\
\hline Aspect: 2 \\
All exemptions and deductions that were used by taxpayer in old tax \\
regime that are not available in new tax regime.
\end{tabular}

Let's see the comparison between old tax regime $\&$ new tax regime:-

\begin{tabular}{|l|l|l|}
\multicolumn{1}{|l}{ Table: 1} \\
\hline Tax slab (₹) & Old tax Rates & New tax Rates \\
\hline $0-2,50,000$ & $0 \%$ & $0 \%$ \\
\hline $2,50,000-5,00,000$ & $5 \%$ & $5 \%$ \\
\hline $5,00,001-7,50,000$ & $20 \%$ & $10 \%$ \\
\hline $7,50,001-10,00,000$ & $20 \%$ & $15 \%$ \\
\hline $10,00,001-12,50,000$ & $30 \%$ & $20 \%$ \\
\hline $12,50,001-15,00,000$ & $30 \%$ & $25 \%$ \\
\hline $15,00,001 \&$ Above & $30 \%$ & $30 \%$ \\
\hline
\end{tabular}

Here we can see in new tax regime income between $5,00,001$ to $7,50,000$ is $10 \%$ and between $7,50,001$ to $10,00,000$ is $15 \%$ however in old tax regime it is flat $20 \%$. In old tax regime there is flat $30 \%$ tax on income above $10,00,000$ but in new tax regime it is divided into three parts i.e. from $10,00,001$ to $12,50,000$ is $20 \%, 12,50,001$ to $15,00,000$ is $25 \%$ and for $15,00,000 \&$ above it is $30 \%$.

\section{$>$ Options available to reduce tax liability in old tax regime:-}

In new tax system government has reduce the tax rates but there is no exemptions \& deductions are available. However in old tax system we can avail all exemptions \& deductions. Over the years government has added various clauses in income tax act to minimise the tax liability of taxpayers. Income tax act provides over $70+$ exemptions \& deductions to taxpayers with which they can reduce their tax 
liability. There are various exemptions included in our salary like House Rent Allowance, Leave Travelling Allowance etc. which are available to reduce taxable income. The way to reduce tax is deductions which are forms with your investment, spending, saving on specific items. Another way to reduce huge tax liability is section $80 \mathrm{C}$ with this taxpayer can decrease taxable income by $1,50,000$.
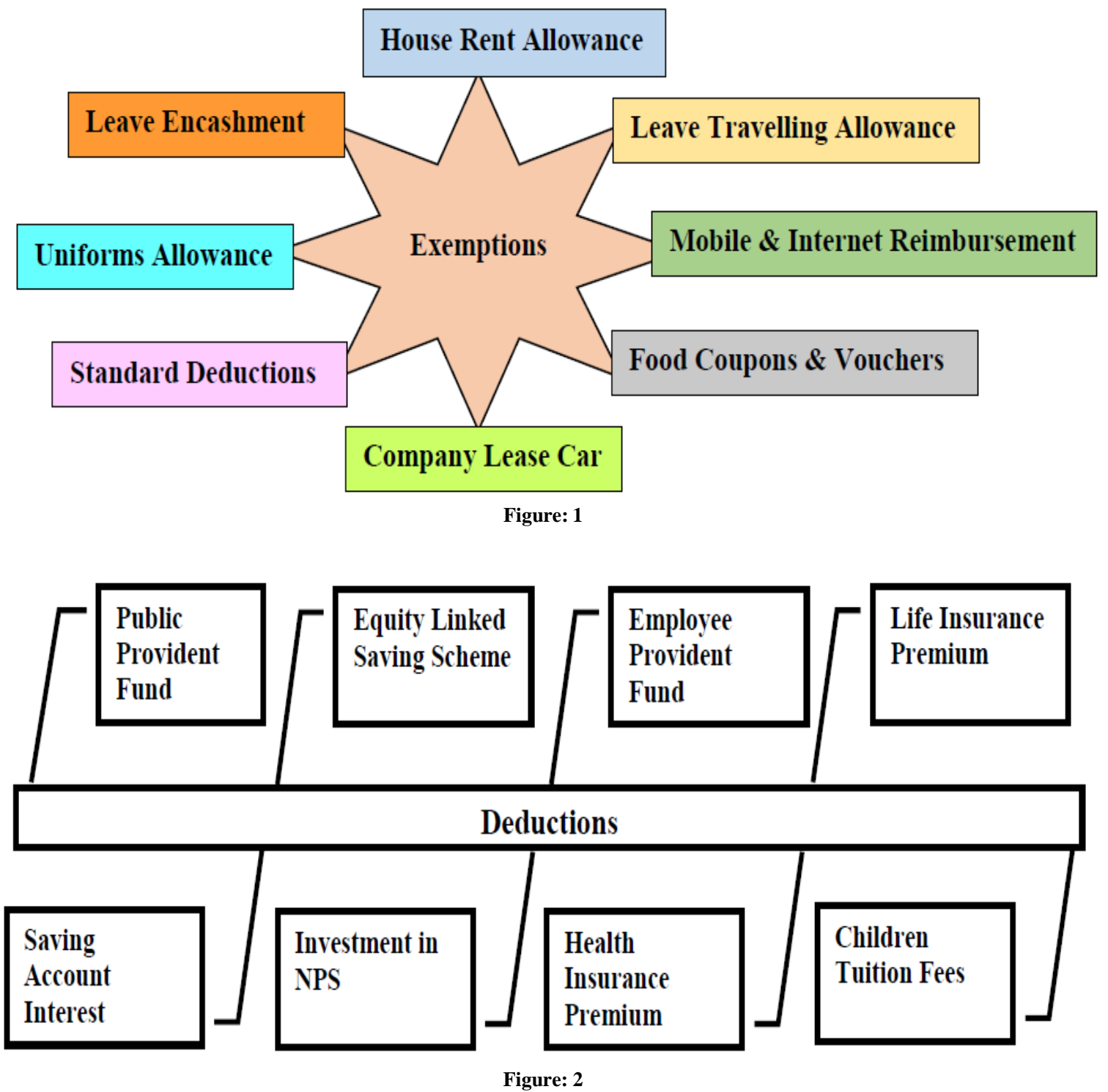

Old Tax Regime Vs New Tax Regime: - Which One is better?

Let's compare new tax regime with old one; in case of new tax structure taxpayer earning Rs.7,50,000 will tax of Rs.25,000 and for those who are earning Rs.10,00,000 will tax Rs.37,500; this is less than old tax regime but taxpayer have to let go all exemptions \& deductions which might reduce tax liability. Here we are going to see some scenarios and understand which tax regime is better.

\section{- Scenario 1:- Claim Limited Exemptions \& Deductions:-}

Suresh is an employee of bank who earns Rs.8, 00,000 P.A. Being salaried he contributes for EPF \& also gets HRA. Apart from this he also avails Leave Travelling Allowance (LTA) of Rs.25, 000. 


\section{Now let's see which tax regime save more money:-}

Table: 2

\begin{tabular}{|l|l|l|}
\hline \multicolumn{4}{|l|}{ Income Tax Calculation Old Vs New Tax Regime } \\
\hline Particulars & Old Tax Regime (Rs.) & New Tax Regime (Rs.) \\
\hline a) Annual Income & $8,00,000$ & $8,00,000$ \\
\hline b) Standard Deductions & $-50,000$ & - \\
\hline c) EPF Contribution (Section 80C) & $-25,000$ & - \\
\hline d) HRA & $-30,000$ & - \\
\hline e) Leave Travelling Allowance & $-25,000$ & - \\
\hline f) Total (Exemptions \& Deductions) & $1,30,000$ & - \\
\hline Net Taxable Income (a-f) & $6,70,000$ & $8,00,000$ \\
\hline
\end{tabular}

\section{Now Let's Calculate Net Tax Payable:-}

Table: 3

\begin{tabular}{|l|l|l|l|l|}
\hline Tax Slab & Old Tax Rates & New Tax Rates & Tax (Old) & Tax (New) \\
\hline $0-2,50,000$ & $0 \%$ & $0 \%$ & - & - \\
\hline $2,50,000-5,00,000$ & $5 \%$ & $5 \%$ & 12,500 & 12,500 \\
\hline $5,00,001-7,50,000$ & $20 \%$ & $10 \%$ & 34,000 & 25,000 \\
\hline $7,50,001-10,00,000$ & $20 \%$ & $15 \%$ & - & 7,500 \\
\hline $10,00,001-12,50,000$ & $30 \%$ & $20 \%$ & - & - \\
\hline $12,50,001-15,00,000$ & $30 \%$ & $25 \%$ & - & - \\
\hline $15,00,001$ \& Above & $30 \%$ & $30 \%$ & - & - \\
\hline Total Tax & - & - & 46,500 & 45,000 \\
\hline Cess (@4\%) & - & - & 1,860 & 1,800 \\
\hline Total Taxable Income & - & - & 48,360 & 46,800 \\
\hline
\end{tabular}

Here we can see Mr. Suresh can minimise his tax liability by choosing new tax regime than old tax regime. He can reduce tax by Rs. 1560 in new tax regime.

- Scenario 2 :- Availing all Major Exemptions \& Deductions:-

For Instance, Mr. Kalpesh earns 18, 00,000 P.A. He avails full deductions under section 80C i.e. Rs.1, 50,000. He has brought health insurance for that he paid premium of Rs.25, 000 \& claim as deduction under Section 80D. He has also made investment of Rs.30, 000 in NPS. He also claim LTA of Rs.25, 000 which is tax exempted.

Table: 4

\begin{tabular}{|l|l|l|}
\hline \multicolumn{4}{|l|}{ Income Tax Calculation Old Vs New Tax Regime } \\
\hline Particulars & Old Tax Regime (Rs.) & New Tax Regime (Rs.) \\
\hline a) Annual Income & $18,00,000$ & $18,00,000$ \\
\hline b) Standard Deductions & $-50,000$ & - \\
\hline c) Section 80C & $-1,50,000$ & - \\
\hline d) HRA & $-40,000$ & - \\
\hline e) Leave Travelling Allowance & $-25,000$ & - \\
\hline f) Health Insurance (Section 80D) & $-25,000$ & \\
\hline g) NPS (Section 80CCD) & $-30,000$ & \\
\hline h) Total (Exemptions \& Deductions) & $3,20,000$ & - \\
\hline Net Taxable Income (a-h) & $14,80,000$ & $18,00,000$ \\
\hline
\end{tabular}

\section{Now Let's Calculate Net Tax Payable:-}

Table: 5

\begin{tabular}{|l|l|l|l|l|}
\hline Tax Slab & Old Tax Rates & New Tax Rates & Tax (Old) & Tax (New) \\
\hline $0-2,50,000$ & $0 \%$ & $0 \%$ & - & - \\
\hline $2,50,000-5,00,000$ & $5 \%$ & $5 \%$ & 12,500 & 12,500 \\
\hline $5,00,001-7,50,000$ & $20 \%$ & $10 \%$ & 50,000 & 25,000 \\
\hline $7,50,001-10,00,000$ & $20 \%$ & $15 \%$ & 50,000 & 37,500 \\
\hline $10,00,001-12,50,000$ & $30 \%$ & $20 \%$ & 75,000 & 50,000 \\
\hline $12,50,001-15,00,000$ & $30 \%$ & $25 \%$ & 69,000 & 62,500 \\
\hline $15,00,001$ \& Above & $30 \%$ & $30 \%$ & - & 90,000 \\
\hline Total Tax & - & - & $2,56,500$ & $2,77,500$ \\
\hline Cess (@4\%) & - & - & 10,260 & 11,100 \\
\hline Total Taxable Income & - & - & $2,66,760$ & $2,88,600$ \\
\hline
\end{tabular}


In this case, Old tax regime is good to choose. By choosing old tax regime instead of new tax regime he can lower the tax liability by Rs. 21,840

\section{CONCLUSION}

Implementation of budget 2020 makes the things complicated as it creates confusion in the minds of taxpayer about tax regime. By analysing all scenarios, we cannot choose any one tax regime because both tax regimes has its own limitations \& advantages. From tax rates point of view the new tax regime is better to opt however anyone want to avail all exemptions \& deductions, in that case the old tax regime perform good. The taxpayer has to decide whether he wants less tax rates or want to avail all exemptions \& deductions. By considering all situations we can conclude that someone who is able to avail all exemptions \& deductions can go for old tax regime and anyone who don't want to avail any exemptions \& deductions, can apply for new tax regime.

\section{Acknowledgement: None}

\section{Conflict of Interest: None}

\section{Source of Funding: None}

\section{REFERENCES}

1. Ashish Mishra \& Brijesh Kumar Yadav. Personal Income Tax in India: An Evaluation. International Journal of Current Research. (2017); 9(1):4590245905

2. Saumen Chattopadhyay \& Arindam Das Gupta. The Personal Income Tax in India: Compliance Costs \& Compliance
Behaviour of Taxpayer. National Institute of Public Finance \& Policy. (2002); 1 :

3. S.M. Alagappan. Indian Tax Structure An Analytical Perspective. International Journal of Management. (2019); 10(3): 0976-6510

4. Gaurav Sharma. A Comprehensive Study of Income Tax Laws in the Taxation system of India. Journal of Critical Review (2020); 7(15): 32833299

5. Pratap Singh. Tax Revenue In India: Trends \& Issues. The Institute of Social \& Economic Change. (2019); 1: 978-81940398-4-6

6. Parul Jain. Anil Kumar Jain. Reforms in Direct Tax Administration in India. Indian Journal of Public Administration. (2020); 66(2): https://doi.org/10.1177/0019556120921 837

7. Rakesh Bhargava. Taxmann. 66. Taxmann; 2021. Page No.01-23

8. Anders Jensen. A study on Personal Income Tax: International Growth Centre; October, 2017

9. K Rajeshwari \& T Susai Mary. The Trends and Pattern of Income Tax India. International Journal of Business and Administration Research Review. (2014); 2(5):2348-0653

10. Pawan K Agrawal. Analysing Progressivity of personal Income Taxes: A case study of India. Indian Economic Review. (1992); 27(2)

How to cite this article: Bagul TD. Income tax regime- old vs new. International Journal of Research and Review. 2021; 8(8): 478-482. DOI: https://doi.org/10.52403/ijrr.20210864 